\title{
FOSTERING STUDENTS' CLAUSE AWARENESS ON READING: THE EXPLORATION ON TRANSITIVITY SYSTEM
}

\section{Muchamad Adam Basori [1], Dian Arsitades Wiranegara [2]}

\author{
[1] mbasori09@bsi.uin-malang.ac.id \\ [2]dwiranegara@gmail.com \\ Maulana Malik Ibrahim State Islamic University, Malang \\ Malang, East Java, Indonesia
}

\begin{abstract}
The opportunity to help students easily read English texts by observing content of the texts, which are construed in students' world experience into limited set of processes type: material, mental, relational, behavioural, verbal and existential has confirmed the necessity of combating misunderstanding clause meanings (process, participant, circumstance). The notion of reading a text is manifested in the processes from a step-by-step lexico-grammatical analysis to contextual description, which are realised as a configuration of transitivity functions which represent the process, the participant situation, the attributes assigned to participant, and the circumstances associated with the process. These are typical patterns of lexico-grammatical realization. This study will examine the transitivity analysis, which provides the recognition of clause awareness on reading English texts. The implication of clause awareness on reading English texts based on the processes is to describe certain feeling, thought, and perception (perceiving through five senses) and creating an ordered technical vocabulary and way of classifying the world.
\end{abstract}

Keywords: nominal and verbal sentences, transitivity, lexico-grammar, contextual description

\section{INTRODUCTION}

The concept of function (Halliday \& Hasan, 1985, p.: 17) is synonymous with that of use. Function is interpreted not just as the use of language but as a fundamental property of language itself, something that is basic to the evolution of the semantic system. The semantic system inspires our one variable parameter of Systemic Functional Linguistic registers, which is called Field. Field, according to Halliday (1994, p.: 106) related to transitivity system, the external reality zone with which the text deals. This amounts to saying that the organisation of every natural language is to be explained in terms of a functional theory, according to Bloor \& Bloor (2004, p.: 107), as a means of representing 'worlds', perceived or imagined. Language encodes our experience, and thereby plays a crucial role in our involvement with other people. Therefore, this has led to the experiential meaning where the sentence as expression of meanings of different kinds. Experiential meaning represents the real world as it is apprehended in human experience. When we are aware of suggesting that our experiences are meaningful, then the way we think what we experience, and what we do every day is strongly related to a matter of experiential metafunction.

The writers focus transitivity analyses on lexicogrammar and its contextual description, and the analyses are applied into the recognition of nominal and verbal sentences of an English text, which is used in teaching English for Economic purposes. Emilia (2014, p.: 149) states that transitivity system belongs to the experiential 
metafunction and is the overall grammatical resource for understanding the meaning. It deals with the content expressed in language: all the doing, sensing, being, saying activities that happen in the world (Halliday, 1994, p.: 107) and (Butt et al 2001, p. :46). Transitivity system can refer to a system for describing the whole clause, rather than just the verb and its object.

Using transitivity system, the writers focus their study on clause awareness in reading a text, in which nominal and verbal sentences are impractically comprehended by students. This study basically works out what causing gaps between readers' world experience and a text they read. In that case, the reading comprehension issue is practically related to the application of transitivity system to get solution in reading. According to Halliday (1994, p.: 107) the system which is dealt with clauses construes the world of experience into a manageable set of process of material, mental and relational types. The process types are between experiential worlds 'inner' and 'outer' what we experience as going on 'out there', in the world around us, and what we experience as going on inside ourselves, in the world of consciousness and imagination. Considering clause awareness in reading in the exploration of transitivity system, outer experience is concerned with reading texts as to doing actions and making it happen, while inner experience is a readingbased text reflection within self-awareness of our states of being. To connect process types above with understanding grammar clauses, Halliday (1994, p.: 107) states that a process, in principle, covers three components: process, participants, circumstance. The components provide the frame of reference in the text interpretation of our experience of what we read.

Butt et al (2001, p. :122) argues what makes the transitivity system in systemic functional linguistics so practical for exploring English texts is perception of the dynamic relationship between language and context. This means that our knowledge of the context allows us to make predictions about lexicogrammar in the process types (material, mental, relational) of a text. In contrast, grammatical analysis of nominal and verbal sentence recognition allows us to understand the context of a text production because the sum of the meanings encoded in the lexicogrammar become signs of the context. In short, being able to control the expression of field through experiential grammar greatly enhances students' ability to manage words into groups, phrases, clauses and clause complexes which encode the specialized relationships of the subject they are studying.

With the grammatical analysis and a set of contextual parameters which apply to the text "Selling Dreams" (Cotton, Falvey, \& Kent, 2003, p. 65) the writers firstly provide tables about transitivity analyses of the clause (2014, p. 149) in terms of who is doing what to whom, and secondly present tables displaying experiential domain (processes, participants, circumstances) and lexicogrammatical analysis to contextual description of the particular text.

From the above argument, the writers believe that the investigation on transitivity system on a text has a strong argument to apply the analyses of lexicogrammar and its contextual description to nominal and verbal sentences.

\section{THE STATEMENTS OF THE PROBLEM}

In this study, the writers analyse and describe the process types. Considering that, there are two issues discussed in the study:

1. What types of process are found in the text "Selling Dreams"?

2. What types of sentence (nominal or verbal) are found in performing metalanguage for writing up the context of situation?

\section{THE OBJECTIVES AND CONTRIBUTION OF THE STUDY}

The main purposes of the study are:

1. To describe the analyses of process types in a text;

2. To determine the context of situation presented in the application of metalanguage for exploring the relation between text and context, particularly the use of field of discourse, and

3. To practically identify both nominal and verbal sentences, which are recognised by students in reading a text.

The paper is intended to contribute systemic functional linguistic point of view in the implementation of transitivity analysis and its description for those who are 
particularly interested in studying the metalanguage of context in the field of discourse.

\section{METHOD}

This is a qualitative research, therefore, the writers believe that the quality of research is the central of the study (Bogman and Biklen, 1992, p.: 36). It can be stated in this type of research that the researchers play a dominant role in their decision in which data is going to be taken. Hence, the subjectivity of the researchers determines the quality of data interpretation.

To obtain reliable data, the writers focused systemic functional linguistics as an approach of the study. First, the writers based a lesson plan for teaching reading of English for Economics in which the text "Selling Dreams' was adopted. Second, the writers selected the text and classified the metalanguage of context based on Field Discourse (Butt et al., 2001, p.: 123). Third, the data were analysed by using clause as representation in transitivity system by Halliday's introduction to Functional Grammar book (1994, p.: 106-175). In line with the study, lexicogrammatical analysis to its contextual description was referred to David Butt's explanation (Butt et al., 2001, p.: 132-133). Fourth, the two students whom are both male and female students of Economics were interviewed after they read the text for detailed comprehension to recognise nominal and verbal sentences.

By applying the method, the writers intended to analyse transitivity of process types and clause meanings (participants and circumstances), which are based on the Halliday's theoretical analyses (1994, p.: 106175). The analysis is given into two types: (1) process types were conducted in the structure of Participants, Processes, and Circumstances. The Participants were based to identify actors, sensers, behavers, or carriers. The Processes were referred to determine verbal, mental, behavioural, relational or existential. The Circumstances were used to recognise Extent, Location, Manner, Cause, Contingency, Accompaniment, Role, Matter, and Angle; (2) According to Butt et al. (2001, p.: 130) in the graphic description of field of discourse whose scope is the field of human experience and activity in the text, the metalanguage of Field of Discourse was applied into three types: Experiential domain, Short term goal, and Long term goal. Experiential domain refers to what the text is all about - the Processes, Participants, and Circumstances. Short term goal is the immediate purpose of the text's production. Long term goal is rather more abstract and refers to the text's place in the larger scheme of things.

\section{THEORETICAL FRAMEWORK}

Since the study is related to metalanguage of context, this research discussed process types and emerging context of situation that motivates the meanings of texts in one of three main ways: field of discourse, tenor or discourse, and mode or discourse. Field of discourse which is only applied into the study, according to Butt et al. (2001, p.: 123), the field means that the field of human experience is encompassed by the text and its purpose is in encompassing it.

Regarding to the above reason, the writers applied the theories stated by Halliday (1994, p.: 106-175) as the grand theory and the supporting theories stated by Butt et al. (2001, p.: 122-149). Harmer (2004, p.: 69) supports reading for detailed comprehension, which is differently practised compared with common reading skills.

\section{Transitivity}

Transitivity system belongs to the experiential metafunction and is the overall grammatical resource for understanding the meaning. It deals with the content expressed in language: all the doing, sensing, being, saying activities that happen in the world. Transitivity system can refer to a system for describing the whole clause, rather than just the verb and its object. (Martin, Matthiessen \& Painter, 1997, p. 100) in (Emilia, 2014, p.: 149)

Transitivity system can be meant (Emilia, 2014, p.: 150) as understanding six different types of process of manageable set in English language. They include material, mental, verbal relatonal, behavioral and exixtential. Each process, Halliday (1994a, p.: 107 in Emilia, 2014, p.: 150) consists, in principle of three components: the process, participants and circumtances. Below is the description of the process. 


\begin{tabular}{llll}
\hline participant & process & participant & Circumtances \\
\hline $\begin{array}{l}\text { Many } \\
\text { students }\end{array}$ & wear & uniforms & To school \\
\hline
\end{tabular}

source: Emilia, 2014, p. 150

The above can be described that the process is expressed in a verb, while the participants, of course, in noun or noun groups and the circumtances are expressed in a prepositional phrase; however they can be expressed in adverbial expressions.

\section{Material Process}

Material process can be said as process of doing (Halliday, 1994a, p. 110 in Emilia, 2014, p. 151). Material processes are expressed physically done something or which is done to some other entity (Gerot \& Wignell, 1994, p. 55). Material process deals with the Actor as the sole participant (in a clause with a Process that is expressed in transitive verb) as it is shown below by Emilia (2014, p. 151)

\begin{tabular}{lllll}
$\begin{array}{l}\text { The } \\
\text { Merapi }\end{array}$ & erupted & In Yogyakarta & \multicolumn{2}{l}{ last year } \\
& & & & \\
\hline Actor & Process: & Circumtance: & Cir: & Loc: \\
& Material & Location: Place & Time & \\
\hline
\end{tabular}

Material process with an Actor and a Goal (active) (a Process expressed in a transitive verb).

\begin{tabular}{llll}
\hline Dian & prepared & $\begin{array}{l}\text { his } \\
\text { thesis }\end{array}$ & in a year \\
\hline Actor & $\begin{array}{l}\text { Process: } \\
\text { material }\end{array}$ & goal & $\begin{array}{l}\text { Circumstance: Loc: } \\
\text { time }\end{array}$ \\
\hline
\end{tabular}

Material processes with a goal can be realised in an expression that uses an agentless passive (Butt, et al, 2001, p. 53 in Emilia, 2014, p. 152):

\begin{tabular}{llll}
\hline This book & was written & in Australia & \\
\hline Goal & Process: & Circumstance: & Loc: \\
& Material & Place & \\
\hline
\end{tabular}

Material Processes with a range and a Beneficiary:

\begin{tabular}{llll}
\hline $\begin{array}{l}\text { Her } \\
\text { husband }\end{array}$ & $\begin{array}{l}\text { has never } \\
\text { done }\end{array}$ & anything & for her \\
\hline Actor & $\begin{array}{l}\text { Process: } \\
\text { material }\end{array}$ & range & Beneficiary \\
\hline
\end{tabular}

By considering Range in particular, Halliday (1994a in Emilia, 2014, p. 152) suggests that a range may be an entity that exists independently of the process, however, this also indicates the domain over the process happens. In English expression, a range may occur in: have a bath, make mistakes, do a little dance, take a quick look, give her usual welcoming smile (Halliday, 199a, p. 147). Material processes can be expressed in transitive verbs with a goal or intransitive verb without a goal Fairclough (2003, p. 142) as this example below shows

\begin{tabular}{lll}
\hline The president & \multicolumn{2}{c}{ Resigned } \\
\hline Actor & & \multicolumn{2}{c}{ Process: material } \\
\hline $\begin{array}{l}\text { The managing } \\
\text { director }\end{array}$ & dismissed & the committee \\
\hline Actor & $\begin{array}{l}\text { Process: } \\
\text { material }\end{array}$ & Goal \\
\hline
\end{tabular}

\section{Mental Process}

Mental processes (sensing verbs) refers to meanings of thinking or feeeling (Eggin, 1994, p. 240 in Emilia, 2014, p. 153). Sensing processes can be understood as people internal world and they are typically used in relation to humans or non-humans given human-like qualities, in describing what humans think, feel, desire, perceive (Derewianka, 2011, p. 22). These sensing processes can be shown below by Derewianka, (2011, p. 22 in Emilia, 2014, p. 153)

\begin{tabular}{llll}
\hline Cognition (thinking) & $\begin{array}{l}\text { Feeling } \\
\text { and } \\
\text { wanting } \\
\text { (affection) }\end{array}$ & $\begin{array}{l}\text { Perceiving } \\
\text { (seeing, } \\
\text { hearing) }\end{array}$ \\
\hline Know & Decide & Like & See \\
Reflect & Consider & Hate & Taste \\
Comprehend & Recall & Dislike & Hear, \\
Believe & Hypothesise & Want & Smell \\
Imagine & Wonder & Wish & Observe \\
Forget & Understand & Need & Notice \\
Remember & Assume & Fear & sense \\
Recollect & Recognise & Enjoy & \\
realise & Infer & & \\
\hline
\end{tabular}

Mental process, as stated by Eggin (1994, p. 242 in Emilia, 2014, p. 154) must have two participants: a senser, that is realised by a human or consciuous participant and a phenomenon, realised by a nominal group or embedded clause summing up what is thought, wanted, perceived or liked/ disliked as it is seen below taken from Emilia (2014, p. 154):

The higher will perhaps any meaningful 


\begin{tabular}{llll}
\hline middle class & not feel & effect \\
\hline senser & $\begin{array}{l}\text { Process: } \\
\text { affection }\end{array}$ & phenomenon & \\
\hline English & $\begin{array}{l}\text { should } \\
\text { taught }\end{array}$ & be & $\begin{array}{l}\text { in all levels of } \\
\text { education }\end{array}$ \\
\hline Goal & $\begin{array}{l}\text { Process: } \\
\text { material }\end{array}$ & $\begin{array}{l}\text { Circumstance: Loc: } \\
\text { Place }\end{array}$ \\
\hline
\end{tabular}

Nonetheless, mental process can sometimes have only one participant, that is in the situation when they project as in the following example:

\begin{tabular}{ll}
\hline I & do believe \\
\hline senser & Process: cognition \\
\hline
\end{tabular}

Sensing processes can refer to actions of perception as those-action-invole the use of human senses: seeing, hearing, tasting, and smelling (Derewianka, 2011, p. 23 in Emilia, 2014, p. 154-155).

\section{Relational Processes: Processes of Being}

Relational processes are processes of being (Halliday, 1994a, p. 119 in Emilia, 2014, p. 158). In English, according to Halliday, relational processes operates with main types:

1. Intensive " $\mathrm{x}$ is a"

2. Circumstantial "is at a" (where is at" stands for "is at, in, on, for, with, about, along, etc)

3. Possessive "x has a"

Each type, halliday says, comes in two distinct modes: a. Attribute "a in an attributive of $x$ ", b. Identifying " $a$ is the identity of $x^{\prime \prime}$. Henceforth, there are six categories of relational processes, and these can be seen below:

\begin{tabular}{lll}
\hline $\begin{array}{l}\text { Mode } \\
\text { type }\end{array}$ & attributive & identifying \\
\hline intensive & Arie is smart & $\begin{array}{l}\text { Smith is the } \\
\text { smartest student. } \\
\text { The smartest student } \\
\text { is Smith. }\end{array}$ \\
\hline circumstantial & $\begin{array}{l}\text { The fair is on a } \\
\text { Tuesday }\end{array}$ & $\begin{array}{l}\text { Tomorrow is the } \\
\text { 10th. The 10th is } \\
\text { tomorrow. } \\
\text { possessive }\end{array}$ \\
$\begin{array}{l}\text { Bobby has a } \\
\text { piano }\end{array}$ & $\begin{array}{l}\text { The red book is } \\
\text { Ika's. } \\
\text { Ika's is the red book. }\end{array}$ \\
\hline
\end{tabular}

The table above (adopted from Halliday, 1994a, p. 119 in Emilia, 2014, p. 158) shows one important difference between the attributive and the identifying modes. The attributive ones are not reversible: there is no form: smart is Arie, which is systematically related to "Arie is smart". However, the identifying ones ereversible, so that $\mathrm{x}$ and the a can be switched around "Arie is the smartest students/ the smartest students is Arie." Therefore, the relational clauses construe being and do this in two different modes: attribution and identification (Martin, Matthiessen, \& Painter, 1997, p. 106; Halliday, 1994a in Emilia, 2014, p. 159). Relational attributive relates a participant to its general characteristics or description, and relational identifying relates a participant to its identity, role or meaning. An identifying clause is not about ascribing or classifying, but defining, with the meaning being " $x$ serves to define the identty of y" (Eggin, 1994, p. 258; see also Halliday, 1994a in Emilia, 2014, p. 159).

Relational clauses (Emilia, 2014, p. 159) can be realised in different forms of be, and linking verbs. Attributive relational clauses where an entity has some quality attributed to it, and the quality is labelled 'the ATTRIBUTE and the entity to which it is ascribed is the CARRIER:

Table: Adopted from Emilia (2014, p. 159)

\begin{tabular}{lll}
\hline Denny & is & diligent \\
\hline Sandra and Peter & Are & $\begin{array}{l}\text { students of English } \\
\text { Letter of UIN }\end{array}$ \\
\hline The story & Sounds & interesting \\
\hline Asis & Is & $\begin{array}{l}\text { a hardworking } \\
\text { person }\end{array}$ \\
\hline Achmad & has turned & into a wise man \\
\hline Whales & Are & mammals \\
\hline (iii) Carrier & $\begin{array}{l}\text { Processes: } \\
\text { Intensive }\end{array}$ & Attribute \\
\hline
\end{tabular}

There are four characteristics of attributive clauses which distinguish them from identifying ones (Halliday, 1994a, p. 120 in Emilia, 2014, p. 159-160): (i) the nominal group that functions as Attributive is typically indefinite. It has either an adjective or a common noun as Head and. If appropriate, an indefinite article (e.g. is/ are wise, is a poet, are poets, is a student, are students, is a teacher, are lecturers). It cannot be a proper noun or pronoun. (ii) the verb realises the process is one of the "ascriptive", classes; [phase: inceptive] become, turn into, grow into, get, go; [phase: durative] reamin, stay (as); keep; [phase, appearance] seem, appear, qualify as, turn out, end up (as); [phase, senseperception] look, sound, smell, feel, taste (like); [neutral] be, feel; (iii) the probe for 
such clauses is what?, how?, or what...like?, for example: what is Ali?, How did Denny seem?, How did the Head of the Department seem?, What will the students be like? What will the result of the exam be like? , (iv) these clauses are not reversible: there is no forms such as: Interesting sounds the story.

\section{Behavioural Processes}

Processes of behaviour are processes of psychological or psychological behaviour (Halliday, 1994, p. 139; Butt, et al, 2000, p. 54 in Emilia, 2014, p. 165) like breathing, dreaming, snoring, smiling, hiccuping, looking, watching, listening, and pondering or thinking carefully. Example of behaviourial processes can be seen below Emilia (2014, p. 165)

\begin{tabular}{ll}
\hline You & are daydreaming! \\
\hline She & is not listening \\
\hline Aziz & is smiling \\
\hline All students & are always laughing \\
\hline Behaver & Process: Behavioural \\
\hline
\end{tabular}

\section{Existential Processes}

Processes of existence represents experience by positing that "there was/ is something" (Eggins, 1994, p. 254 in Emilia, 2014, p. 166) "something exists or happens" it involves "there" and typically employ the verb to be or synonyms such as exist, arise, occur. The word "there" in such clauses is neither a participant nor circumstance-it has no representational function in the transitivity structure of the clause, but it serves to indicate the feature of existence, and it is needed interpersonally as a subject of the verb (Halliday \& Matthiessen, 2004, p. 257 in Emilia, 2014, p. 166).

\section{Circumstances}

Talking about different events, behaviours or states of being there is often a need to specify where, when, how, with whom, etc. These are referred to adverbial groups, allowing us to add meaning to a clause by locating events in time and space or describing the surrounding conditions or circumstances (Droga \& Humphrey, 2003, p. 36).

Halliday (1994, p. 152) identifies nine types of circumstances, as illustrated in Table below, with examples of circumstances (in italics).

\begin{tabular}{|c|c|}
\hline $\begin{array}{c}\text { Types of } \\
\text { Circumstances }\end{array}$ & Examples \\
\hline Extent & $\begin{array}{l}\text { He studied English for seven years. } \\
\text { (duration) }\end{array}$ \\
\hline Location & $\begin{array}{l}\text { He did his Masters in Sydney } \\
\text { University (place). } \\
\text { In } 2014 \text { the Indonesian people } \\
\text { elected a new president (time). }\end{array}$ \\
\hline Manner & $\begin{array}{l}\text { Indonesian people may not get } \\
\text { much benefit from the fact [[that an } \\
\text { Indonesia's contestant becomes the } \\
\text { winner of the Miss Universe contest]] } \\
\text { (means). } \\
\text { Some school students at remote } \\
\text { places may be treated unfairly } \\
\text { (quality). } \\
\text { She cannot work as has as her } \\
\text { brother does (comparison). }\end{array}$ \\
\hline Cause & $\begin{array}{l}\text { 'Activist' students at universities } \\
\text { could not finish their study on time } \\
\text { because of their absence of } \\
\text { classroom meetings (reason). }\end{array}$ \\
\hline Contingency & $\begin{array}{l}\text { If the national curriculum policy } \\
\text { changes over one time in a year, } \\
\text { then it will appear [[what we call a } \\
\text { 'fashion show]] among teachers in } \\
\text { Indonesia (condition). } \\
\text { Though it is not comfortable, it } \\
\text { makes students creative } \\
\text { (concession). }\end{array}$ \\
\hline Accompaniment & $\begin{array}{l}\text { The teacher and his students went } \\
\text { to Surabaya with his school } \\
\text { principal (accompaniment). } \\
\text { All students, along with their } \\
\text { parents are invited to the } \\
\text { Thanksgiving } \\
\text { (accompaniment). }\end{array}$ \\
\hline Role & $\begin{array}{l}\text { The implementation of death } \\
\text { penalty is considered as a real } \\
\text { deterrent effect (guise). } \\
\text { The 'Putri Indonesia' pageant can } \\
\text { be exploited as an arena [[to } \\
\text { promote business]] (product). }\end{array}$ \\
\hline Matter & $\begin{array}{l}\text { He can talk about public policy very } \\
\text { comprehensively (matter). } \\
\text { Smith is going to talk about his } \\
\text { proposal project to his general } \\
\text { manager (matter). }\end{array}$ \\
\hline Angle & $\begin{array}{l}\text { According to Halliday, all languages } \\
\text { have three metafunctions: } \\
\text { experiential, interpersonal, and } \\
\text { textual metafunctions (angle). }\end{array}$ \\
\hline
\end{tabular}

\section{READING FOR DETAILED COMPREHENSION}

Realizing the importance of reading ability in the present time, in this context (Harmer, 2004, p. 69) students need to be able to read for detailed comprehension information of language. It must be seen by students as something very different from the reading skills, such as: scanning, skimming, or reading for pleasure. It must come to concentrate on the very specific details of they 
read. This competence can lead them to obtain so many kinds of information and knowledge. Somehow, the students should also be motivated to understand that in the process of reading there is a communication between a writer and reader. In this activity, reading deals with decoding and the comprehension process in which a reader tries to understand what a writer has put in a text. In the activity, the reader actively has to relate his or her prior knowledge or schemata to comprehend the text better.

Henceforth, reading for detailed information has led to a principle behind the teaching of reading. First of all, (Harmer, 2004, p. 70) reading requires active skill and occupation. Students are trained to understand what the words mean as well as trained to engage with the text they are reading. Therefore, students should be encouraged to respond to the content of a reading text, not just to the language. It is important to learn reading text in a way students use language. They should also pay attention the number of paragraphs they contain and how many times they use relative clause. The meaning, the message of the text, is just as important and students should be given chance to respond towards the message.

Reading text is the cognitive activities of understanding sentences, words, ideas, descriptions etc. Therefore, teachers should integrate the reading text activities into interesting class sequences by using topics for discussion and further tasks.

\section{FINDINGS AND DISCUSSION}

In this section, the writers put forward result and description. The analysis is performed by showing the transitivity for each.

The following text identified nominal and verbal is the situational description of language, context and text from Financial Times, world business newspaper.

The text 'SELLING DREAMS' (Cotton, Falvey, \& Kent, 2003, p. 65)

\section{by John Munch}

Ferrari, Italy's maker sports and racing cars, $\underline{\text { is }}$ among the three most recognizable brands in the world. The company got its high profile among the world's corporate giants without the help, for most of its existence, of an advertising department. Only as recently as 1993 did Ferrari create a marketing department. "Just parking our exciting automobiles is enough to draw the crowds" writes Gian Luigi Longinotti-Buitoni the author of a book called Selling Dreams.

Customers are now spending more money on products they desire rather than on products they simply need. All companies must therefore produce goods of very high quality more importantly, they must establish a brand for years to come by giving it emotional qualities that match customers' strongest desires. Like Ferrari, all companies must create and sell dreams. Longinotti-Buitoni gives some interesting statistics about markets for luxury goods worldwide: Switzerland with 220 Ferraris sold in 1997 is the largest market per capita for the car maker's products; the company, on the other hand, sells only $2,7 \%$ of its cars to women. Rolex and the highest number of luxury watches are sold in Italy, while Japan has been consistently the leading market in the world for leather goods from Gucci, Ferragamo, Hermes and Louis Vuitton. China amazingly, appears to be drinking a lot of Hennessy cognac.

\section{Clause Transitivity Analyses}

The following analysis of the clause is in terms of who is doing what to whom.

1. Ferrari, Italy's maker sports and racing cars, is among the three most recognizable brands in the world.

\begin{tabular}{llll}
\hline $\begin{array}{l}\text { Participant: } \\
\text { Carrier }\end{array}$ & $\begin{array}{c}\text { Process: } \\
\text { Intensive }\end{array}$ & \multicolumn{1}{c}{ Attribute } & $\begin{array}{c}\text { Circumstance: } \\
\text { Angle }\end{array}$ \\
\hline $\begin{array}{l}\text { Ferrari, } \\
\text { Italy's maker }\end{array}$ & is & $\begin{array}{l}\text { among the } \\
\text { three most }\end{array}$ & in the world \\
sports and & & $\begin{array}{l}\text { recognizable } \\
\text { reconds }\end{array}$ & \\
racing cars, & & brands &
\end{tabular}

2. The company got its high profile among the world's corporate giants without the help, for most of its existence, of an advertising department.

\begin{tabular}{ccll}
\hline $\begin{array}{c}\text { Participant: } \\
\text { Actor }\end{array}$ & $\begin{array}{l}\text { Process: } \\
\text { Material }\end{array}$ & \multicolumn{1}{c}{ Goal } & \multicolumn{1}{c}{$\begin{array}{c}\text { Circumstance: } \\
\text { Role }\end{array}$} \\
\hline $\begin{array}{c}\text { The company } \\
\text { got }\end{array}$ & $\begin{array}{l}\text { its high } \\
\text { profile for most of its } \\
\text { among the } \\
\text { existence of an } \\
\text { advertising } \\
\text { corporate } \\
\text { giants }\end{array}$ \\
& & \\
& & \\
& &
\end{tabular}


3. Only as recently as 1993 did Ferrari create a marketing department.

\begin{tabular}{|c|c|c|c|c|c|}
\hline $\begin{array}{c}\text { Circu } \\
\text { mstan } \\
\text { ce: } \\
\text { Mann } \\
\text { er }\end{array}$ & $\begin{array}{l}\text { Numera } \\
\text { tive }\end{array}$ & $\begin{array}{c}\text { auxili } \\
\text { ary }\end{array}$ & $\begin{array}{l}\text { Particip } \\
\text { ant: } \\
\text { Actor }\end{array}$ & $\begin{array}{l}\text { Proce } \\
\text { ss: } \\
\text { Mater } \\
\text { ial }\end{array}$ & goal \\
\hline $\begin{array}{l}\text { Only } \\
\text { as } \\
\text { recent } \\
\text { ly as }\end{array}$ & 1993 & did & Ferrari & $\begin{array}{l}\text { creat } \\
\text { e }\end{array}$ & $\begin{array}{l}\text { a } \\
\text { marketing } \\
\text { departme } \\
\text { nt }\end{array}$ \\
\hline
\end{tabular}

4. "Just parking our exciting automobiles is enough to draw the crowds" writes Gian Luigi Longinotti-Buitoni the author of a book called Selling Dreams.

\begin{tabular}{lll}
\hline \multicolumn{1}{c}{ Goal } & $\begin{array}{c}\text { Process: } \\
\text { material }\end{array}$ & Participant: Actor \\
\hline "Just parking our & writes & Gian Luigi \\
exciting & & $\begin{array}{l}\text { Longinotti-Buitoni } \\
\text { the author of a } \\
\text { automobiles is }\end{array}$ \\
$\begin{array}{l}\text { enough to draw } \\
\text { the crowds" }\end{array}$ & $\begin{array}{l}\text { book called Selling } \\
\text { Dreams. }\end{array}$ \\
\hline
\end{tabular}

5. Customers are now spending more money on products they desire rather than on products they simply need.

\begin{tabular}{cccccccc}
\hline Partici & Proces & Par & Pro & Cir & Parti & Circum & Affectio \\
pant: & s: & tici & ces & cu & cipan & stance: & n \\
Actor & Materi & pa & s: & mst & t: & Manne & \\
& al & nt: & Sen & anc & Acto & r & \\
& & Act & sin & e: & r & & \\
& & or & g & Ma & & & \\
& & & & nne & & & \\
\hline Custo & are & the & des & rat & they & simply & need \\
mers & now & y & ire & her & & & \\
& spendi & & & tha & & & \\
& ng & & & n & & & \\
& more & & & on & & & \\
& money & & & pro & & & \\
& on & & & duc & & & \\
produc & & & ts & & & \\
ts & & & & & & \\
\hline
\end{tabular}

6. All companies must therefore produce goods of very high quality more importantly, they must establish a brand for years to come by giving it emotional qualities that match customers' strongest desires.

\begin{tabular}{|c|c|c|c|c|c|}
\hline $\begin{array}{c}\text { Participant } \\
\text { Actor }\end{array}$ & \multicolumn{2}{|c|}{$\begin{array}{l}\text { Process: } \\
\text { Material }\end{array}$} & Goal & \multicolumn{2}{|c|}{$\begin{array}{c}\text { Circumstance: } \\
\text { Manner }\end{array}$} \\
\hline \multirow[t]{2}{*}{$\begin{array}{l}\text { All } \\
\text { companies }\end{array}$} & \multicolumn{2}{|c|}{$\begin{array}{l}\text { must } \\
\text { therefore } \\
\text { produce }\end{array}$} & goods & \multicolumn{2}{|c|}{$\begin{array}{l}\text { of very high } \\
\text { quality more } \\
\text { importantly }\end{array}$} \\
\hline & & & \multicolumn{3}{|c|}{ Circumstance } \\
\hline $\begin{array}{l}\text { Participa } \\
\text { nt: Actor }\end{array}$ & $\begin{array}{l}\text { Proces } \\
\text { s: } \\
\text { Materi } \\
\text { al }\end{array}$ & Goal & $\begin{array}{c}\text { Circumsta } \\
\text { nce: Extent }\end{array}$ & $\begin{array}{l}\text { Proce } \\
\text { ss: } \\
\text { Materi } \\
\text { al }\end{array}$ & Goal \\
\hline they & $\begin{array}{l}\text { must } \\
\text { establi } \\
\text { sh }\end{array}$ & $\begin{array}{l}\text { a } \\
\text { bran } \\
\text { d }\end{array}$ & $\begin{array}{l}\text { for years to } \\
\text { come by } \\
\text { giving it } \\
\text { emotional } \\
\text { qualities }\end{array}$ & $\begin{array}{l}\text { that } \\
\text { match }\end{array}$ & $\begin{array}{l}\text { custome } \\
\text { rs' } \\
\text { stronges } \\
\text { t desires }\end{array}$ \\
\hline
\end{tabular}

7. Like Ferrari, all companies must create and sell dreams.

\begin{tabular}{cccc}
\hline $\begin{array}{c}\text { Circumstance: } \\
\text { Cause }\end{array}$ & $\begin{array}{c}\text { Participant: } \\
\text { Actor }\end{array}$ & $\begin{array}{c}\text { Process: } \\
\text { Material }\end{array}$ & Goal \\
\hline Like Ferrari & all companies & $\begin{array}{l}\text { must create } \\
\text { and sell }\end{array}$ & dreams \\
& & & \\
\hline
\end{tabular}

8. Longinotti-Buitoni gives some interesting statistics about markets for luxury goods worldwide: Switzerland with 220 Ferraris sold in 1997 is the largest market per capita for the car maker's products; the company, on the other hand, sells only $2,7 \%$ of its cars to women.

\begin{tabular}{|c|c|c|c|c|}
\hline $\begin{array}{l}\text { Participant: } \\
\text { Actor }\end{array}$ & $\begin{array}{l}\text { Process } \\
\text { Materia }\end{array}$ & \multicolumn{2}{|c|}{ goal } & $\begin{array}{c}\text { Circumstance: } \\
\text { Matter }\end{array}$ \\
\hline $\begin{array}{l}\text { Longinotti- } \\
\text { Buitoni }\end{array}$ & gives & $\begin{array}{l}\text { som } \\
\text { intel } \\
\text { stati }\end{array}$ & $\begin{array}{l}\text { esting } \\
\text { tics }\end{array}$ & $\begin{array}{l}\text { about markets } \\
\text { for luxury goods } \\
\text { worldwide }\end{array}$ \\
\hline $\begin{array}{l}\text { Participa } \\
\text { nt: } \\
\text { Carrier }\end{array}$ & $\begin{array}{c}\text { Circumstance } \\
\text { : } \\
\text { Accompanim } \\
\text { ent }\end{array}$ & $\begin{array}{c}\text { Process } \\
: \\
\text { Intensi } \\
\text { ve }\end{array}$ & $\begin{array}{l}\text { Attribu } \\
\text { te }\end{array}$ & $\begin{array}{l}\text { Circumstan } \\
\text { ce: Role }\end{array}$ \\
\hline $\begin{array}{l}\text { Switzerla } \\
\text { nd }\end{array}$ & $\begin{array}{ll}\text { with } & 220 \\
\text { Ferraris } & \text { sold } \\
\text { in } 1997 & \end{array}$ & is & $\begin{array}{l}\text { the } \\
\text { largest } \\
\text { market } \\
\text { per } \\
\text { capita }\end{array}$ & $\begin{array}{l}\text { for the car } \\
\text { maker's } \\
\text { products }\end{array}$ \\
\hline $\begin{array}{c}\text { Participant: } \\
\text { Actor }\end{array}$ & & $\begin{array}{l}\text { ocess: } \\
\text { aterial }\end{array}$ & Goal & $\begin{array}{c}\text { Circumstance: } \\
\text { Role }\end{array}$ \\
\hline $\begin{array}{l}\text { the } \\
\text { company }\end{array}$ & $\begin{array}{l}\text { on the } \\
\text { other } \\
\text { hand }\end{array}$ & & $\begin{array}{l}\text { only } \\
2,7 \% \\
\text { of its } \\
\text { cars }\end{array}$ & to women \\
\hline
\end{tabular}

9. Rolex and the highest number of luxury watches are sold in Italy, while Japan has been consistently the leading market in the world for leather goods from Gucci, Ferragamo, Hermes and Louis Vuitton.

\begin{tabular}{|c|c|c|}
\hline Goal & $\begin{array}{l}\text { Process: } \\
\text { Material }\end{array}$ & Circumstance: Location \\
\hline $\begin{array}{l}\text { Rolex and the } \\
\text { highest number of } \\
\text { luxury watches }\end{array}$ & re sold & in Italy \\
\hline
\end{tabular}
luxury watches

\begin{tabular}{|c|c|c|c|c|c|}
\hline & \multirow{2}{*}{$\begin{array}{c}\text { Carri } \\
\text { er }\end{array}$} & \multirow{2}{*}{\multicolumn{2}{|c|}{$\begin{array}{l}\text { Process: } \\
\text { Intensive }\end{array}$}} & \multirow[b]{2}{*}{ Attribute } & \multirow[b]{2}{*}{$\begin{array}{c}\text { Circumstanc } \\
\text { e: Manner }\end{array}$} \\
\hline & & & & & \\
\hline $\begin{array}{l}\text { whil } \\
\text { e }\end{array}$ & $\begin{array}{l}\text { Japa } \\
\text { n }\end{array}$ & $\begin{array}{l}\text { has } \\
\text { been }\end{array}$ & $\begin{array}{l}\text { consi } \\
\text { leadi }\end{array}$ & $\begin{array}{ll}\text { lly } & \text { the } \\
\text { arket } & \end{array}$ & $\begin{array}{l}\text { in the world } \\
\text { for leather } \\
\text { goods from } \\
\text { Gucci, } \\
\text { Ferragamo, } \\
\text { Hermes and } \\
\text { Louis } \\
\text { Vuitton }\end{array}$ \\
\hline
\end{tabular}


10. China amazingly, appears to be drinking a lot of Hennessy cognac.

\begin{tabular}{|c|c|c|c|c|}
\hline \multicolumn{2}{|c|}{ Value/Identifying } & \multirow{2}{*}{$\begin{array}{c}\text { Process: } \\
\text { Intensiv } \\
\text { e }\end{array}$} & \multicolumn{2}{|c|}{ Token/Identified } \\
\hline $\begin{array}{c}\text { Carrie } \\
\mathbf{r}\end{array}$ & $\begin{array}{c}\text { Circumstanc } \\
\text { e: Manner }\end{array}$ & & $\begin{array}{c}\text { Attribut } \\
\mathrm{e}\end{array}$ & $\begin{array}{l}\text { Circumstanc } \\
\text { e: Role }\end{array}$ \\
\hline China & amazingly & appears & $\begin{array}{l}\text { to be } \\
\text { drinkin } \\
g\end{array}$ & $\begin{array}{l}\text { a lot of } \\
\text { Hennessy } \\
\text { cognac }\end{array}$ \\
\hline
\end{tabular}

\section{From lexicogrammatical analysis to contextual description \\ Field of Discourse}

\section{Lexicogrammatical Analysis}

\begin{tabular}{|c|c|c|c|}
\hline $\begin{array}{l}\text { Experiential } \\
\text { Meanings }\end{array}$ & \multirow{3}{*}{$\begin{array}{l}\text { As a result } \\
\text { of our } \\
\text { analysis } \\
\text { and our } \\
\text { knowledge } \\
\text { of context } \\
\text { of culture } \\
\text { we can } \\
\text { write up } \\
\text { our } \\
\text { description } \\
\text {. }\end{array}$} & $\begin{array}{ll}\text { Field of } \\
\text { Discourse }\end{array}$ & Commentary \\
\hline $\begin{array}{l}\text { Process Type: } \\
\text { frequent } \\
\text { material } \\
\text { processes } \\
\text { (verbal } \\
\text { sentences): } \\
\text { got, create, } \\
\text { writes, } \\
\text { spending, } \\
\text { produce, } \\
\text { establish, sell, } \\
\text { gives, and sold. }\end{array}$ & & $\begin{array}{l}\text { Experientia } \\
\text { l domain: } \\
\text { Dreams have } \\
\text { a business } \\
\text { market } \\
\text { potential }\end{array}$ & \multirow{3}{*}{$\begin{array}{l}\text { Clauses } 5,6 \\
\text { and } 7 \text { of the } \\
\text { second } \\
\text { paragraph } \\
\text { have been } \\
\text { foregrounded } \\
\text { by the } \\
\text { material } \\
\text { process } \\
\text { (verbal } \\
\text { groups), the } \\
\text { use of present } \\
\text { simple and by } \\
\text { complex } \\
\text { embedding } \\
\text { around } \\
\text { relational } \\
\text { processes } \\
\text { (processes of } \\
\text { mental: } \\
\text { nominal } \\
\text { groups). } \\
\text { This } \\
\text { foregroundin } \\
\text { g underlines } \\
\text { the essential } \\
\text { meaning of } \\
\text { long-term } \\
\text { goal. }\end{array}$} \\
\hline $\begin{array}{l}\text { Participants: } \\
\text { Ferrari, Italy's } \\
\text { maker sports } \\
\text { and racing } \\
\text { cars, The } \\
\text { company, } \\
\text { Ferrari, Gian } \\
\text { Luigi } \\
\text { Longinotti- } \\
\text { Buitoni the } \\
\text { author of a } \\
\text { book called } \\
\text { Selling } \\
\text { Dreams, } \\
\text { Customers, All } \\
\text { companies, } \\
\text { Longinotti- } \\
\text { Buitoni, } \\
\text { Switzerland, } \\
\text { Japan, China }\end{array}$ & & $\begin{array}{l}\text { Short-term } \\
\text { goal: } \\
\text { to create a } \\
\text { marketing } \\
\text { department, } \\
\text { just parking } \\
\text { our exciting } \\
\text { automobiles } \\
\text { is enough to } \\
\text { draw the } \\
\text { crowds, } \\
\text { goods, } \\
\text { brand, } \\
\text { customers' } \\
\text { strongest } \\
\text { desires, } \\
2,7 \% \text { of its } \\
\text { cars sold to } \\
\text { women }\end{array}$ & \\
\hline $\begin{array}{l}\text { Circumstance } \\
\text { : } \\
\text { in the world, } \\
\text { for most of its } \\
\text { existence of an } \\
\text { advertising } \\
\text { department, } \\
\text { only as } \\
\text { recently as, } \\
\text { rather than on } \\
\text { products, } \\
\text { simply, of very } \\
\text { high quality } \\
\text { more } \\
\text { importantly, } \\
\text { for years to } \\
\text { come by giving }\end{array}$ & & $\begin{array}{l}\text { Long-term } \\
\text { goal: } \\
\text { All } \\
\text { companies } \\
\text { running } \\
\text { business like } \\
\text { Ferrari must } \\
\text { enable } \\
\text { customers to } \\
\text { spend their } \\
\text { money to } \\
\text { buy } \\
\text { products of } \\
\text { the } \\
\text { companies. }\end{array}$ & \\
\hline
\end{tabular}

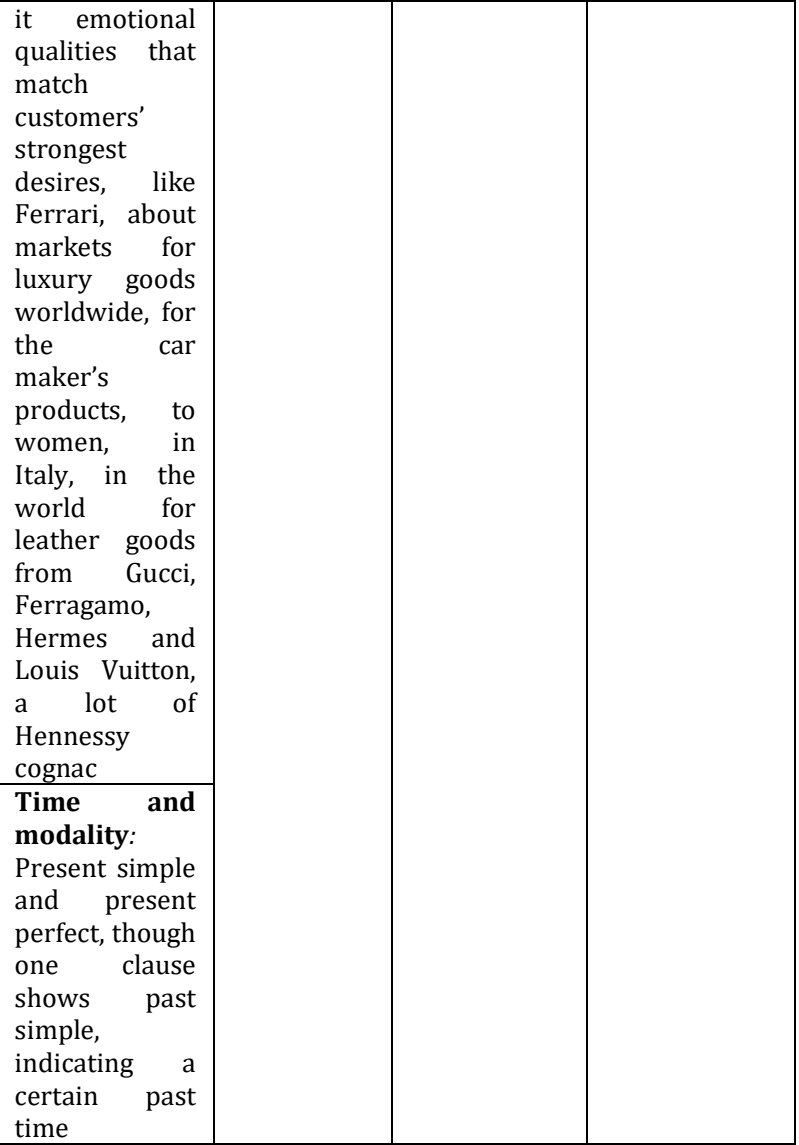

\section{CONCLUSION}

From the data, it can be concluded that the study covers the following.

a. The most frequent material processes indicating verbal sentences in the text consist of got, create, writes, spending, produce, establish, sell, gives, but also notice the passive voice are sold in sentence 9 . The sentence 4 has challenged the students, without consciousness, who had identified it as nominal sentence due to two predicates 'is' and 'write' work in the same sentence. However, the double quote (") punctuation provides a clause with which 'is' shows nominal. On top of these verbal sentences, the text is written more verbal sentences than nominal ones because context of situation is strongly related to business orientation. It means the text asks readers to do more real profitable actions than mental ones or even existential or behavioural.

b. Nominal sentences, in contrast, are proceeded by intensive, meaning to identify things such ' $x$ ' that belong to ' $y$ '. Sentences 1, 4, 8, 9, and 10 are nominal 
that indicates relational processes or processes of being. The participants of those sentences show Carrier, which are defined in Relational Processes, with the meaning being ' $x$ serves to define the identity of y' (Halliday, 1994, p. 119).

c. Related to processes of existential and behavioural, no existential and behavioural processes related to clauses are found in the text. The text is not written in the processes as existential because it serves to indicate the feature of existence, in which the contextual text does not match with of situation. Similarly, behavioural processes are not manifested in most sentences owing to processes of physiological or psychological behaviour.

d. Relating to Participants, interactants create and clarify their role relationships. First, the writer exemplifies Ferrari as the car production, which has an established company that sells dreams. Gian Luigi Longinotti-Buitoni, on the other hand, writes a book of luxurious goods and proves interesting statistical evidence of how dreams can sell.

e. Dealing with Circumstances, the text adds extra details to descriptions in relation to eight types, except Contingency. From the most types of Circumstances, it can be concluded that the text shows an information report that illuminates processes of Material. f. The text has more verbal sentences than nominal ones. Verbal sentences show got, create, writes, spending, produce, establish, sell, gives, and sold which meant to be recognised in the table of lexicogrammatical analysis to its contextual description.

g. Referring to the above transitivity clause, it can be captured that the result of the analysis can be best described in accordance to the knowledge of context of culture. In this context, it is clear that the knowledge of this context culture is marketing, and the text indicates a register of business. As it can be said that (Selling Dreams) the text has a business market potential due to context of situation covered in it. Hence, the companies mentioned in the text should be able to sell their dreams.

h. The two students who have identified nominal and verbal sentences in the process types and participants as well as circumstances help them understand what is going on in the text. In line with Droga \& Humphrey (2003, p. 79), this helpful recognition can assist students to take a more critical reading of the text. They are able to reveal a certain structural pattern of language that leaners are focusing on control of knowledge of experiential grammar patterns which typically structure different text types.

\section{REFERENCE}

American Psychological Association. (2001). Publication manual of the American Psychological Association (5th ed.). Washington, DC: Author.

Cotton, D., Falvey, D., \& Ken, S. (2003). Market Leader. UK: Longman.

Bloor, T. \& Bloor, M. (2004). The functional analysis of English: A Hallidayan Approach (2nd Ed.). London: Arnold

Bogman \& Bigle. (1992). Qualitative Research for Education - An introduction to theory and methods. Boston and London: Allya and Bacon.

Butt et al. (2001). Using functional grammar: an explorer's guide. Macquarie: NCELTR.

Droga, L. \& Humphrey, S. (2003). Grammar and meaning. An introduction for primary teachers. Berry, NSW: Target Texts. 
Emilia, E. (2014). Introducing Functional Grammar. Bandung: PT DUNIA PUSTAKA JAYA.

Halliday, M.A.K. \& Hasan, R. (1985). Language, Context, and Text: Aspect of language in a socialsemiotic perspective. Victoria: Deakin University

Halliday, M.A.K. (1994). An intro to functional grammar (2nd Ed.). China: Edward Arnold (Publishers) Limited.

Harmer, J. (2004). How to Teach English. Essex: Longman

Thompson, Neil. (2003). Communication and Language: A handbook of theory and practice. New York: Palgrave MacMillian.

University of Canberra \& Academic Skills Program. (2007). A guide to Referencing with examples in the APA \& Harvard Styles. Australia: Author. 